\title{
Signaling mechanisms leading to regulation of proliferation and differentiation of the mesenchymal chondrogenic cell line RCJ3.1C5.18 in response to IGF-I
}

\author{
Sonia Ciarmatori, Daniela Kiepe, Anke Haarmann, Ulrike Huegel and Burkhard Tönshoff \\ University Children's Hospital, Im Neuenheimer Feld 153, 69120 Heidelberg, Germany \\ (Requests for offprints should be addressed to B Tönshoff; Email: burkhard.toenshoff@med.uni-heidelberg.de) \\ S Ciarmatori and D Kiepe contributed equally to this work
}

\begin{abstract}
Since IGF-I is an important chondrocyte growth factor, we sought to examine the intracellular mechanisms by which it exerts two of its pivotal effects, stimulation of proliferation and differentiation. We used the mesenchymal chondrogenic cell line RCJ3.1C5.18, which progresses spontaneously to differentiated growth plate chondrocytes. This differentiation process could be enhanced by exogenous IGF-I. Pharmacological inhibition of the phosphatidylinositol-3 (PI-3) kinase by LY294002, mitogen-activated protein kinase/extracellular signal-regulated kinase (MAPK/ERK)1/2 by U0126, the protein kinase (PK) A pathway by H-89 or KT5720, and the PKC pathway by bisindolylmaleimide suppressed IGF-I-stimulated cell proliferation. In contrast, IGF-I-enhanced early cell differentiation, as assessed by collagen type II and aggrecan gene expression, was not affected by MAPK/ERK1/2 pathway inhibition, but significantly diminished by inhibition of the PI-3 kinase, the PKC and the PKA pathway. Moreover, terminal differentiation of chondrocytes in response to IGF-I, as assessed by gene expression of alkaline phosphatase, Indian hedgehog, and collagen type $\mathrm{X}$, were only interrupted by $\mathrm{PI}-3$ kinase pathway inhibition. In conclusion, IGF-I exerts its differential effect on chondrocyte proliferation vs differentiation through the use of at least four partially interacting intracellular signaling pathways, whose activity is temporarily regulated. When chondrocytes progress from proliferating cells to early and terminal differentiating cells, they progressively inactivate IGF-I-related intracellular signaling pathways. This mechanism might be essential for the complex and cell stage-specific anabolic action of IGF-I in the growth plate.
\end{abstract}

Journal of Molecular Endocrinology (2007) 38, 493-508

\section{Introduction}

The growth plate is a dynamic tissue in which cells undergo a developmental program from resting cells to proliferation, maturation, and hypertrophy, until they reach terminal differentiation and produce the mineralized matrix that supports endochondral bone formation (Kronenberg 2003, van der Eerden et al. 2003). Insulin-like growth factor-I (IGF-I) is a potent growth factor in the growth plate, exerting its actions by both endocrine and paracrine/autocrine mechanisms. When the growth hormone (GH)/IGF-I system is inactivated, very little growth occurs in the postnatal period. In fact, only $17 \%$ of postnatal growth in the mouse occurs independent of the GH/IGF-I axis (Lupu et al. 2001). Of the $83 \%$ of growth governed by the GH/ IGF-I axis, IGF-I alone contributes 35\%, much more than the $14 \%$ contributed by GH alone. Another large (34\%) component of growth was found to be dependent on the presence of both GH and IGF-I.

It is known from cell culture (Ohlsson et al. 1994, Monsonego et al. 1995, Reinecke et al. 2000, Olney et al. 2004) and gene knockout experiments (Wang et al. 1999,
2004) that IGF-I stimulates both proliferation and differentiation of growth plate chondrocytes in vitro and in vivo. IGF-I exerts its biological effect by binding to the transmembrane type 1 IGF receptor, whose activation leads to the extensive tyrosyl-phosphorylation of insulinreceptor substrate-1, which acts as a docking protein for the downstream signal transduction pathways (Parrizas et al. 1997, Tsakiridis et al. 2001). Two canonical pathways, the phosphatidylinositol-3 (PI-3)-kinase and the mitogenactivated protein kinase/extracellular signal-regulated kinase (MAPK/ERK) 1/2 pathway, and the IGF-I-activated protein kinase (PK) A and PKC intracellular cascades have been reported previously to mediate the mitogenic, differentiating and antiapoptotic response to IGF-I (Grey et al. 2003), but the relative contributions to the diverse cellular actions of IGF-I vary according to the cell type (Petley et al. 1998). For example, in brown adipocytes, skeletal muscle cells and Schwann cells, IGF-I-mediated cell differentiation is signaled through the PI-3-kinase pathway (Valverde et al. 1997, Kaliman et al. 1998, Ogata et al. 2004), whereas in human breast cancer cells the same pathway is mainly involved in IGF-I-stimulated mitogenesis (Dufourny et al. 1997). It is therefore necessary to 
study IGF-I signaling in individual tissues to determine the role of each pathway in that specific cell type.

The signaling cascades may be temporally separated or may have a cross-talk and partially overlap (Daaka $e t$ al.
1997, Stork \& Schmitt 2002, Yoon et al. 2002). For example, in skeletal myoblasts, IGF-I initially induces proliferation and inhibits myogenesis (Coolican et al. 1997). Subsequently, it promotes the cell cycle exit and stimulates
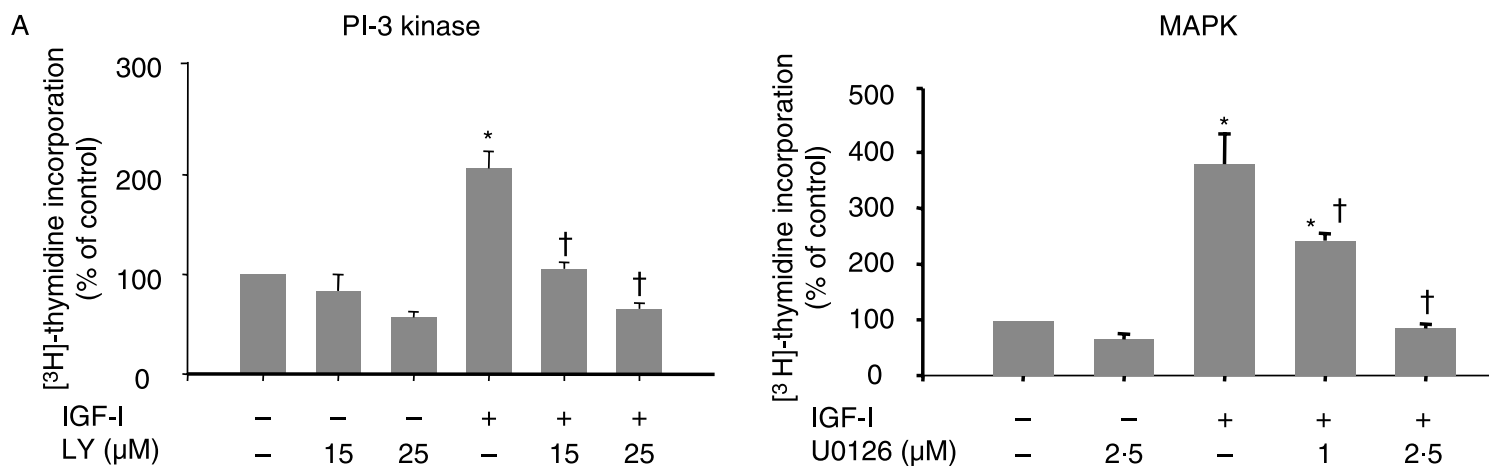

PKC
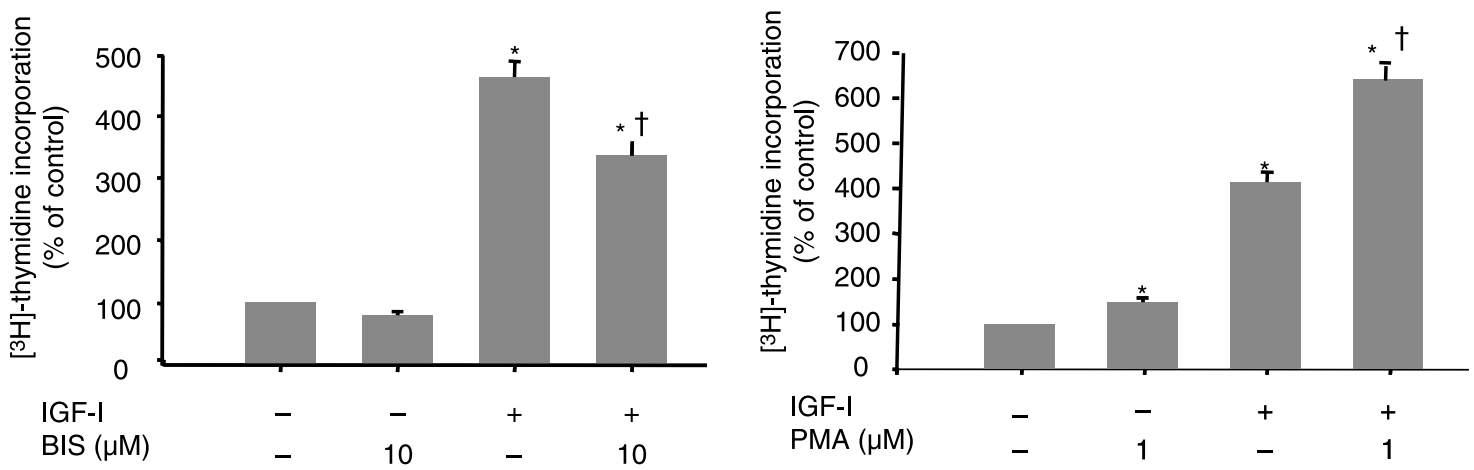

PKA
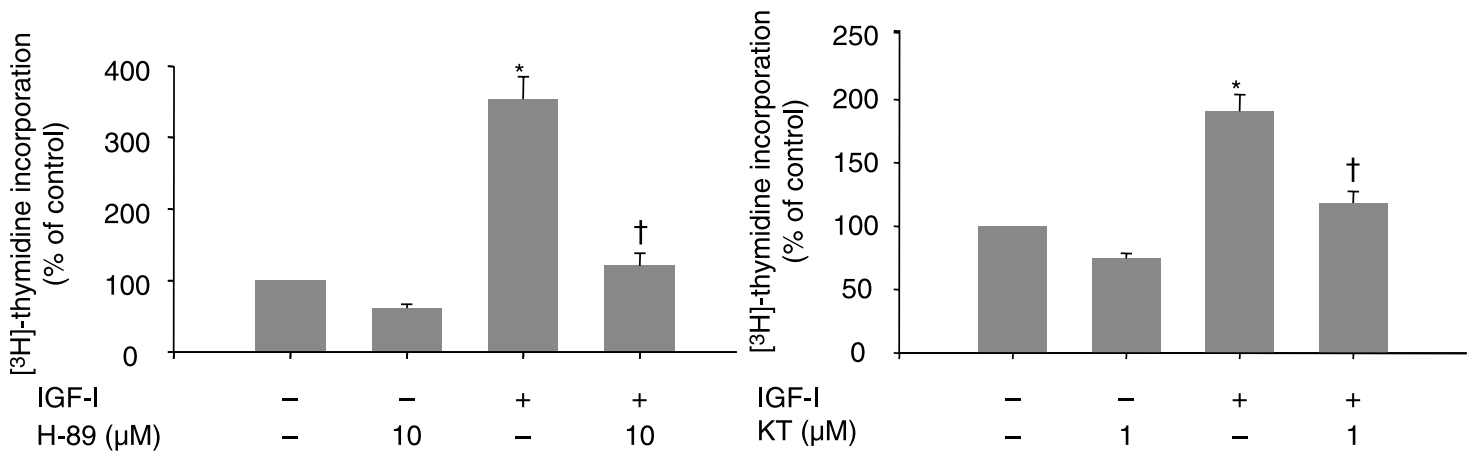

B

$\begin{array}{lllll}\text { IGF-I }(100 \mathrm{ng} / \mathrm{ml}) & - & + & + & + \\ \operatorname{LY}(25 \mu \mathrm{M}) & - & - & - & + \\ \text { U0126 }(2.5 \mu \mathrm{M}) & - & - & + & -\end{array}$

$\begin{array}{ccccc}- & + & + & + & \text { IGF-I }(100 \mathrm{ng} / \mathrm{ml}) \\ - & - & - & + & \mathrm{H}-89(10 \mu \mathrm{M}) \\ - & - & + & - & \mathrm{BIS}(10 \mu \mathrm{M})\end{array}$

PCNA

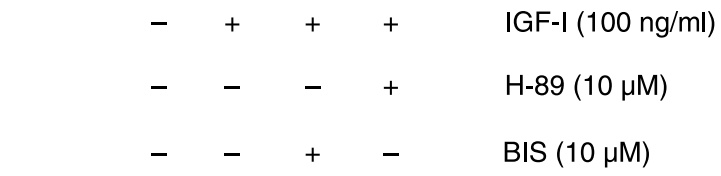


differentiation. Signaling through the MAPK/ERK1/2 pathway in these cells mediates the initial proliferative effect of IGF-I. On the other hand, preventing the late IGFI-induced decrease in ERK1/2 phosphorylation blocks IGF-I-stimulation of myogenin mRNA, indicating that the time-dependent, opposing effects of IGF-I on skeletal muscle cell differentiation are mediated, at least in part, by biphasic but opposite effects on activation of the MAPK/ ERK1/2 signaling pathway (Adi et al. 2002).

Little is known about the intracellular signaling pathways by which IGF-I exerts its effect on cell proliferation and differentiation in growth plate chondrocytes. In articular chondrocytes, IGF-I regulates differentiation, maintenance of the differentiated phenotype, and apoptosis via a PI-3 kinase pathway that modulates ERK, p38 kinase, and PKC signaling (Oh \& Chun 2003). The role of the PKC pathway in both spontaneous and IGF-I-enhanced differentiation in growth plate chondrocytes has not been studied so far.

In the present study, we therefore examined the role of various IGF-I-activated signaling pathways in chondrocyte proliferation and differentiation. We used the mesenchymal RCJ3.1C5.18 (RCJ) cell line as a cell culture model, which is widely used for growth plate chondrocyte research (McEwen et al. 1999, Weksler et al. 1999, Cohen et al. 2006). RCJ cells derive from fetal rat calvaria (Grigoriadis et al. 1996, McDougall et al. 1996, Lunstrum et al. 1999). They undergo over 2 weeks of culture in the presence of dexamethasone a reproducible, time-dependent progression from chondroprogenitors to hypertrophic chondrocytes, accompanied by an upregulation of collagen type II and deposition of cartilage-specific proteoglycans in a sequence that mimics the phenotype of chondrocytes of the growth plate. Furthermore, they do not express IGF-I; therefore the action of this hormone can be studied without interference from endogenous IGFs (Spagnoli et al. 2001).

\section{Materials and methods}

\section{Reagents}

Minimum essential medium (MEM) was purchased from cc Pro (Neustadt, Germany), fetal calf serum from Paa
Laboratories (Pasching, Austria), ascorbic acid, $\beta$-glycerophosphate and dexamethasone were from Sigma. Recombinant human IGF-I was supplied by Bachem (Weil am Rhein, Germany); LY294002 (LY), H89, bisindolylmaleimide I (BIS), phorbol myristate acetate (PMA) and KT-5720 were obtained from Calbiochem (San Diego, CA, USA) and U0126 from Promega. $\left[{ }^{3} \mathrm{H}\right]$-thymidine and enhanced chemiluminescent (ECL) reagents were provided from Amersham Pharmacia. The antibodies to phosphorylated ERK1/2 (p-ERK1/2), total ERK1/2, phosphorylated Akt

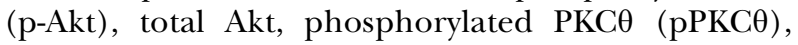
$\beta$-actin, the horseradish peroxidase-conjugated (antirabbit and antimouse) antibodies were from Cell Signaling Technology (Frankfurt am Main, Germany), antibodies to proliferating cell nuclear antigen (PCNA), PKC $\alpha$, and PKA $\alpha$ were purchased from Santa Cruz Biotechnologies (Santa Cruz, Heidelberg, Germany).

\section{Cell culture}

RCJ3.1C5.18 cells (kindly provided by Dr Anna Spagnoli, Department of Pediatrics, Vanderbilt University Medical Center, Nashville, Tennessee, USA) were grown at $37^{\circ} \mathrm{C}$ in humidified $5 \% \mathrm{CO}_{2}$ atmosphere in MEM (with Earle's salts) supplemented with $1 \mathrm{mM} N$-acetyl-L-glutamine, $10 \mathrm{mM}$ Hepes, $100 \mathrm{U} / \mathrm{ml}$ penicillin-streptomycin, $2 \mathrm{mM}$ sodium pyruvate, $15 \%$ heat-inactivated fetal bovine serum, $10^{-7} \mathrm{M}$ dexamethasone and studied within 25 passages. Cell viability was tested with the tetrazolium salt (MTT) assay. These cells sequentially acquire at 7 days of culture markers of chondrocytic differentiation (type II collagen) and progressively acquire at 10 and 14 days of culture markers of terminal differentiation (type $\mathrm{X}$ collagen and alkaline phosphatase; Lunstrum et al. 1999, Spagnoli et al. 2001, data not shown).

\section{$\left[{ }^{3} \mathrm{H}\right]$-Thymidine assay}

The extent of thymidine incorporation into DNA was determined as uptake of radioactivity in precipitated material, as described previously (Kiepe et al. 2001). Briefly, chondrocytes were grown in 96-well plates to confluence for 3 days; thereafter, the cultures were

Figure 1 The mitogenic effect of IGF-I in RCJ cells is mediated by signaling pathways involving the PI-3 kinase, the MAPK/ERK $1 / 2$, the PKA and, to a lesser extent, the PKC pathways. (A) RCJ cells were cultured until confluence, serum-starved for $12 \mathrm{~h}$ and stimulated by IGF-I $(100 \mathrm{ng} / \mathrm{ml})$ in the presence or absence of inhibitors of the respective signaling pathways (LY294002 (LY) for the PI-3 kinase pathway; U0126 for the MAPK/ERK1/2 pathway; an bisindolylmaleimide (BIS) for the PKC pathway; H-89 and KT-5720 for the PKA pathway) and the activator PMA for the PKC pathway for an additional $48 \mathrm{~h}$. Control cells were cultured without IGF-I in the absence or presence of the same concentrations of inhibitors. $\left.{ }^{3} \mathrm{H}\right]$-Thymidine incorporation into the acid-extractable pool was determined by scintillation counting and used as a measure of DNA synthesis, as described in Materials and methods. Data are means $\pm S$.E. Statistics by ANOVA were for 12 parallel wells per group from three independent experiments. ${ }^{*} P<0.05$ vs control; ${ }^{\dagger} P<0.05$ vs IGF-I. (B) Inhibition of the PI-3 kinase, the MAPK/ERK1/2, PKA and to a lesser extent, the PKC pathways reduces IGF-I-driven cell proliferation as assessed by PCNA protein content. RCJ cells were cultured until confluence, serum-starved for $12 \mathrm{~h}$ and stimulated by IGF-I (100 ng/ml) in the presence or absence of inhibitors of the different signaling pathways for an additional $12 \mathrm{~h}$. PCNA protein content was evaluated by Western immunoblotting; representative autoradiographs of a total of three experiments are shown. 
changed to serum-free medium. After $12 \mathrm{~h}$, various concentrations of inhibitors with or without IGF-I were added to the medium and the incubation was continued for a further $48 \mathrm{~h}$. The rate of chondrocyte proliferation was assessed by incubating the cells with $3 \mu \mathrm{Ci} / \mathrm{ml}\left[{ }^{3} \mathrm{H}\right]$-thymidine for the final $4 \mathrm{~h}$. Subsequently, cells were rinsed twice with PBS. The radiolabeled DNA was precipitated by acetic acid and dissolved in $1 \mathrm{M} \mathrm{NaOH} .\left[{ }^{3} \mathrm{H}\right]$-Thymidine incorporation into the acid-extractable pool as a measure of DNA synthesis was determined by scintillation counting.

\section{Quantitative RT-PCR}

For analysis of collagen type II, collagen type X, aggrecan, Indian hedgehog (Ihh), and alkaline phosphatase (ALP) mRNA abundance, cells were cultured in differentiating medium from day $4(80-90 \%$ of confluence). After 3 days, at day 7 of culture, for investigating the expression of collagen type II and aggrecan, as markers for early differentiation (Sive $e t$ al. 2002), and at day 14 , for investigating the expression of collagen type X, Ihh, and ALP, as markers for terminal differentiation (Lai \& Mitchell 2005), cells were serumstarved for $12 \mathrm{~h}$ and stimulated with $100 \mathrm{ng} / \mathrm{ml}$ IGF-I for 12 additional hours, in the presence or absence of the indicated inhibitors, and then harvested. RNA was isolated by using the RNeasy mini columns (Qiagen) and reverse transcribed by using Moloney Murine Leukemia Virus reverse transcriptase and oligo(dt)/ random hexamer primers (10:1) from Applied Biosystems (Darmstadt, Germany). For quantitative analysis, real time RT-PCR was performed using the ABI 7000 (Applied Biosystems) according to the manufacturer's protocol. The following set of primers was chosen by the Primer Express program (Applied Biosystems) for collagen type II (forward, 5'-GGCAAGACCATCATCGAGTACC-3'; reverse, 5'-CCCTATGTCCACACCAAATTCC-3'), for collagen type X (forward, 5'-GGTAAAGAGATTTCAGTAAGAGGAGAACA-3'; reverse, $5^{\prime}$-ACTTCCATAGCCTGGCTTTCC-3 ${ }^{\prime}$ ), for ALP (forward, 5'-AACAACCTGACTGACCCTTCCC-3'; reverse, $5^{\prime}$-TCAATCCTGCCTCCTTCCACT- ${ }^{\prime}$ ), for Ihh (forward, 5'-CGACCGAAATAAGTACGGACTACT G-3'; reverse, 5' ${ }^{\prime}$-TCAGAC TTGACAGAGCAATGAACG-3'), aggrecan (forward, 5'-ATCGAAGGGGACTTCCGCTG$3^{\prime}$; reverse, 5'-ATCACCACACAGTCCTCTCCG-3') and for $18 \mathrm{~S}$ (forward, $5^{\prime}$-AGTTGGTGGAGCGATTTGTC-3'; reverse, $5^{\prime}$-GCTGAGCCAGTTCAGTGTAGC-3'). The software provided from the company allowed the quantitative detection of fluorescence by the incorporation of the substance SyberGreen into the amplification products. Amplification was performed in the presence of Universal Mastermix (PE Applied Biosystems) with SyberGreen to detect PCR products at the end of each amplification step, and the results were analyzed as already reported (Kiepe $e t$ al. 2006).

\section{Western immunoblotting}

For total cell homogenate cells were incubated with the indicated substances, scraped in $50 \mu \mathrm{l}$ ice-cold lysis buffer containing a mixture of proteinase and phosphatase inhibitors, and cell extracts were treated as reported previously (Hömme et al. 2003, Kiepe et al. 2006). Cytosol membrane and nuclear factions of cells were prepared by previously described procedures (Hoeflich et al. 2004). Briefly, homogenates were centrifuged at $600 \mathrm{~g}$ for $20 \mathrm{~min}$ at $4{ }^{\circ} \mathrm{C}$ to pellet a crude nuclear fraction. The supernatant was recentrifuged at $100000 \mathrm{~g}$ for $30 \mathrm{~min}$ at $4{ }^{\circ} \mathrm{C}$ to pellet membranes and the supernatant containing the cytosol. Nuclei and membranes were washed in Tris-buffered saline and lysed in lysis buffer containing a mixture of proteinase and phosphatase inhibitors. Protein amount was measured by the BCA method, and $20 \mu \mathrm{g}$ protein were boiled ( $5 \mathrm{~min}$ ) and electrophoresed on a $12 \%$ separating SDS-polyacrylamide gel. Separated proteins were transferred to a polyvinylidene flouride (PVDF) membrane (Millipore, Eschborn, Germany). The membranes were blocked in 5\% milk for $1 \mathrm{~h}$ at room temperature, incubated overnight with the first antibody (dilution 1:2000 for $\mathrm{PKC} \alpha$, dilution 1:4000 for PKA $\alpha$, total Akt, $\beta$-actin and PCNA in 3\% milk; dilution 1:2000 for p-Akt, pPKC $\theta$, PKC $\theta$, p-ERK1/2 and ERK1/2 in 3\% BSA), washed extensively over a period of $30 \mathrm{~min}$ with Tris Buffer SalineTween $200.05 \%$, and then incubated for $1 \mathrm{~h}$ with the secondaryantibody (dilution 1:2000 in 3\% milk), followed by further washing over a period of $30 \mathrm{~min}$. The protein bands were visualized using a chemiluminescent detection system and Hyperfilm ECL film (Amersham Pharmacia Biotech) according to the manufacturer's directions.

The successful separation of cytosol, cell membrane, and nuclear fractions was verified by incubating each cell fraction with specific marker proteins. Glyseraldehyde-3-phosphate dehydrogenase (GAPDH), a marker for the cytosol (Sirover 1997), was abundant in the cytosolic fraction and nearly absent in the nuclear and membrane fractions. The membrane fraction was enriched with Na-K-ATPase, a known marker for cell membranes (Mrsny et al. 1988), and the nuclear fraction was identified by positive cAMP-response element binding protein staining, a known marker for the nucleus (Roesler et al. 1988; data not shown).

\section{Statistical analysis}

All experiments were performed at least thrice. For measurements with the ABI7000 system, samples were run in duplicate to account for technical and biological variability within and between experiments. Data are 
given as means \pm s.E. All the data were examined for normal and non-Gaussian distribution by the Kolmogorov-Smirnov test. For comparison among normally distributed groups, one-way ANOVA followed by pairwise multiple comparisons (Student-Newman-
Keuls method) or the Student's $t$-test were used as appropriate. For non-normally distributed data, the non-parametric Kruskal-Wallis test followed by an all pairwise multiple comparison (Dunnett's method) was used. $P<0.05$ was considered statistically significant.

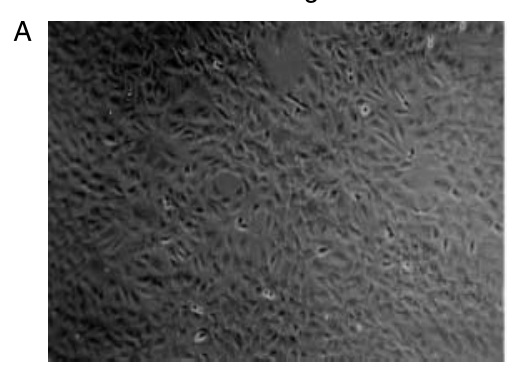

Day 3

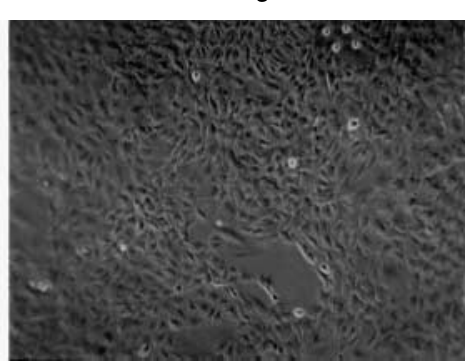

Day 14

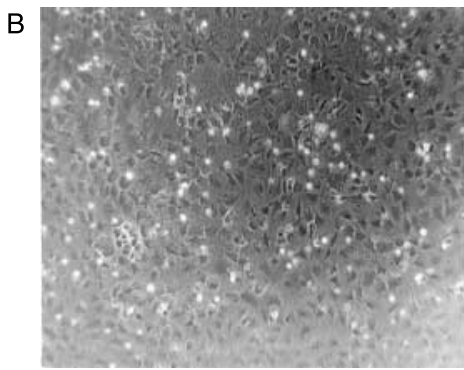

Day 7

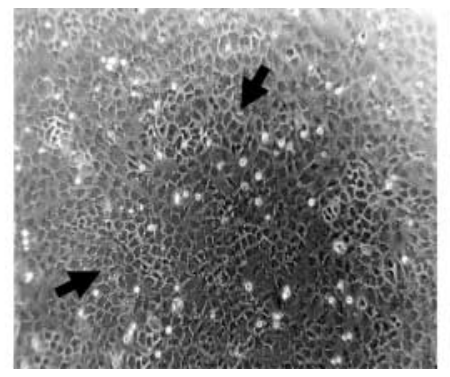

Day 7 + IGF- I

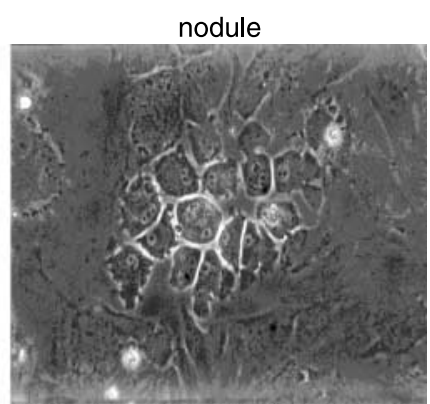

Day $7+$ IGF- I
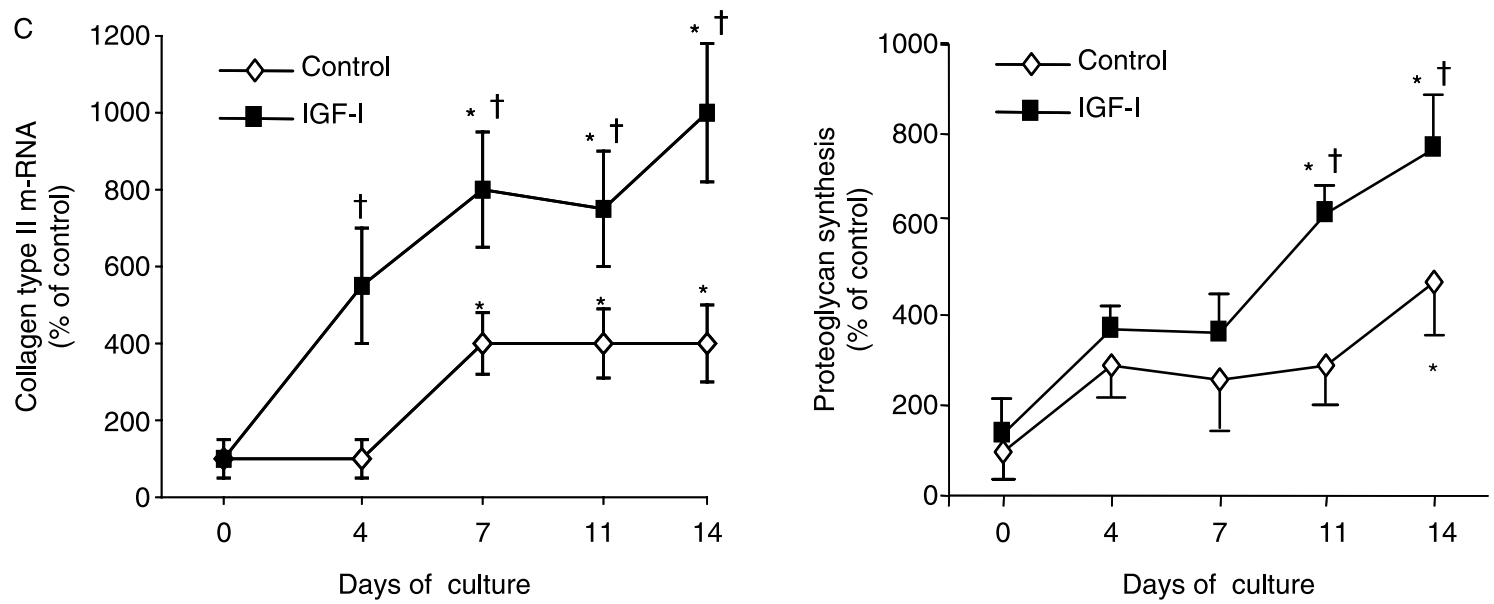

Figure 2 IGF-I enhances differentiation of RCJ cells. RCJ cells were grown until day 4, when they reached $80-90 \%$ of confluence. Then, cells were allowed to differentiate in medium supplemented with ascorbic acid $(50 \mu \mathrm{g} / \mathrm{ml})$ and $\beta$-glycerophosphate $(10 \mathrm{mM})$. (A) Phasecontrast photomicrographs of proliferating (day 3 ) and differentiating (day 14) cells are shown (magnification $\times 40$ ). (B) Cells were grown as described above. At day 7 of culture, cells were serum-starved for $12 \mathrm{~h}$, and subsequently grown in the absence (left panel, magnification $\times 40$ ) or presence of IGF-I $(100 \mathrm{ng} / \mathrm{ml}$ ) for an additional $12 \mathrm{~h}$ (middle panel, magnification $\times 40)$. The arrows indicate cartilage-like nodules. Right panel, a higher magnification (magnification $\times 400)$ of a typical cartilage nodule is shown. (C) Spontaneous and IGF-I-induced differentiation of RCJ cells was assessed by collagen type II mRNA expression, determined by real-time PCR, as a marker for early chondrocyte differentiation (left panel), and by sulfate proteoglycan accumulation, quantified by alcian blue staining, as a marker of terminal chondrocyte differentiation (right panel). The data in the left panel represent mean values ( \pm s.E.) of a total of seven experiments, the data in the right panel of three typical experiments. Statistics by ANOVA. ${ }^{\star} P<0.05$ vs day $4 ;{ }^{\dagger} P<0.05$ IGF-I vs control. 


\section{Results}

The mitogenic effect of IGF-I in RCJ cells is mediated by signaling pathways involving PI-3 kinase, MAPK/ERK1/2, PKC and PKA

To identify the intracellular pathways subserving the mitogenic action of IGF-I in chondrocytes, RCJ cells were treated with IGF-I alone or in the presence of specific pharmacological inhibitors of PI-3 kinase (LY294002), MAPK/ERK1/2 (U0126), PKC (BIS) and PKA (H-89 and KT-5720) signaling pathways. In addition, the effect of PMA, an activator of the PKC pathway, on cell proliferation was tested. Cell viability after $48 \mathrm{~h}$ of incubation with $25 \mu \mathrm{M}$ LY294002 was approximately $80 \%$, indicating that these substances were not cytotoxic at the indicated conditions. IGF-I at a concentration of $100 \mathrm{ng} / \mathrm{ml}$ stimulated proliferation of RCJ cells, as assessed by incorporation of $\left[{ }^{3} \mathrm{H}\right]-$ thymidine, three- to four-fold (Fig. 1A). The mitogenic effect of IGF-I was partially sensitive to the inhibition and activation of the PKC pathway and completely abolished by the respective inhibitors of the PI-3 kinase, MAPK/ERK1/2 and PKA kinase pathway (Fig. 1A). These data indicate that IGF-I-stimulated cell prolifer- ation of RCJ cells is mediated through the PI-3 kinase, MAPK/ERK1/2 and PKA signaling pathways, whereas the PKC pathway plays only a minor role. Since the results obtained with the PKA inhibitor $\mathrm{H}-89$ were similar to those obtained with KT5720, we decided to use only H-89 in the subsequent series of experiments.

Comparable results were obtained, when chondrocyte proliferation was assessed by PCNA protein content in cell lysate (Fig. 1B). PCNA is a nuclear protein required for cell-cycle progression and cellular proliferation. The PCNA content in RCJ cells exposed to IGF-I clearly increased. Coincubation with the respective inhibitors of the PI-3 kinase, MAPK/ERK1/2, or PKA pathways markedly reduced IGF-I-induced PCNA protein content, whereas coincubation with the PKC pathway inhibitor BIS had only a weak inhibitory effect.

\section{IGF-I enhances differentiation of RCJ cells}

The mesenchymal RCJ cell line spontaneously differentiates from displayed polygonal-shaped isolated chondrocytes to cartilage nodules over 4-14 days of culture in differentiating medium, in the presence of dexamethasone (Grigoriadis et al. 1996).
A

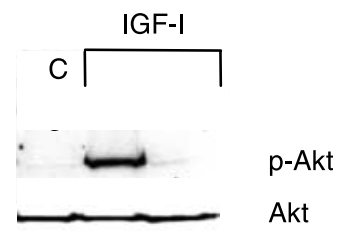

LY294002 ( $\mu \mathrm{M})$

$-\quad-\quad 25$

Day 7

B

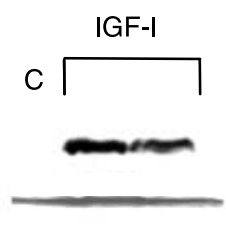

p-Akt

Akt

U0126 $(\mu \mathrm{M})$
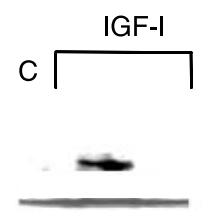

p-Akt

Akt

$\operatorname{LY} 294002(\mu \mathrm{M}) \quad-\quad-\quad 25$

Day 14

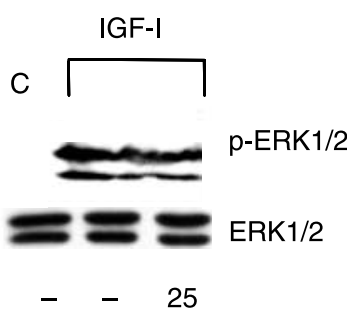

Figure 3 IGF-I activates key signaling molecules of the PI-3 kinase and MAPK/ERK1/2 pathways. (A) Cells were cultured in differentiating medium until day 7 (left panel) and day 14 (right panel), serum-starved for $12 \mathrm{~h}$ and incubated for $1 \mathrm{~h}$ with IGF-I $(100 \mathrm{ng} / \mathrm{ml})$ in the presence or absence of $25 \mu \mathrm{M}$ LY294002. Cell lysates were subjected to Western immunoblot analysis and the respective membranes were probed with specific antibodies against p-Akt and total Akt. Representative autoradiographs of a total of three independent experiments are shown. (B) After $12 \mathrm{~h}$ of starvation, cells were treated with IGF-I and the MAPK/ERK $1 / 2$ inhibitor U0126 for $1 \mathrm{~h}$ and the respective membranes were probed with specific antibody against $p$-AKT and total AKT (left panel). Cells were treated as described under $A$ and the respective membranes were probed with specific antibodies against p-ERK $1 / 2$ and total ERK $1 / 2$ (right panel). Blots are representative for two independent experiments. 
Differentiation of RCJ cells was promoted by incubating the cells with $\beta$-glycerophosphate and ascorbic acid from day 4 of culture, as described in Materials and methods. Differentiating cultures can be distinguished from proliferating cells in their tendency to become extensively nodulated, as shown in the light microscopy pictures (Lunstrum et al. 1999; Fig. 2A).

To evaluate changes in RCJ morphology due to the presence of IGF-I, differentiating cells were cultured in differentiating medium from day 4 of culture until day 7 , followed by serum-deprivation for $12 \mathrm{~h}$ and treatment with IGF-I (100 ng/ml) for an additional $12 \mathrm{~h}$. As shown in Fig. 2B, IGF-I enhanced nodule formation of differentiating chondrocytes. Furthermore, IGF-I treatment stimulated the gene expression of collagen type II, a marker of early chondrocyte differentiation two-fold compared with untreated cells (Fig. 2C, left panel).
Exogenous IGF-I also enhanced the synthesis of sulfated proteoglycans, a marker of terminally differentiated chondrocytes, on day 11 and 14 of culture (Fig. 2C, right panel). These results indicate that IGF-I stimulates the chondrogenic differentiation of RCJ cells.

\section{IGF-I-enhanced early differentiation is mediated through the PI-3 kinase, PKA and PKC signaling pathways, IGF-I-enhanced terminal differentiation through the PI-3 kinase pathway}

Next, we sought to investigate whether IGF-I activates key signaling molecules of the respective pathways in differentiating chondrocytes. RCJ cells were cultured in differentiating medium from day 4 onwards. At the indicated time points, cells were serum-deprived for $12 \mathrm{~h}$ and subsequently treated with IGF-I in the

A

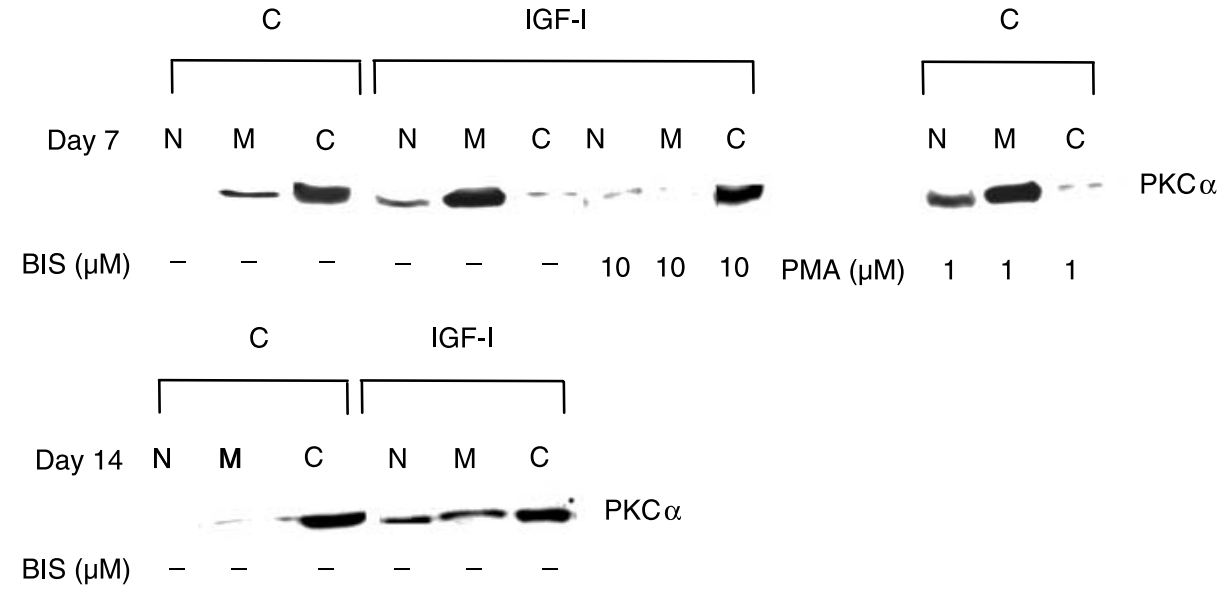

B

C IGF-I
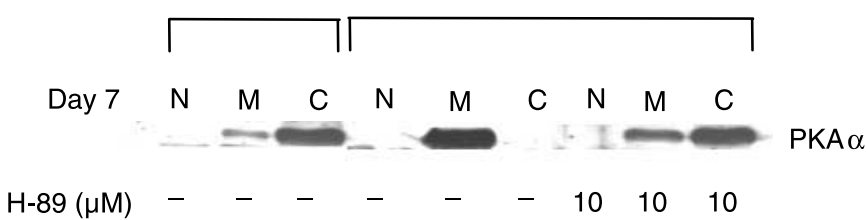

C IGF-I

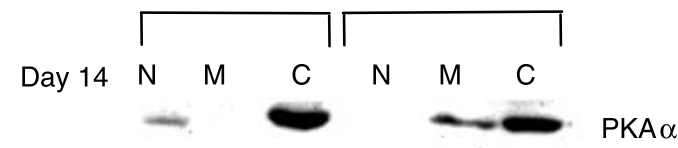

$\mathrm{BIS}(\mu \mathrm{M})$

Figure 4 IGF-I activates key signaling molecules of the PKC and PKA pathways. (A and B). At day 7 and day 14 of culture, cells were treated with IGF-I $(100 \mathrm{ng} / \mathrm{ml})$ and the respective inhibitors or PMA, an activator of PKC, for $30 \mathrm{~min}$. The nuclear (N), membrane (M), and cytosolic (C) fractions were prepared by ultracentrifugation and immunoblotted with antibodies specific for PKC $\alpha$ (A) and PKA $\alpha$ (B). $\beta$-actin was used as a loading control. Blots are representative for three independent experiments. 
A

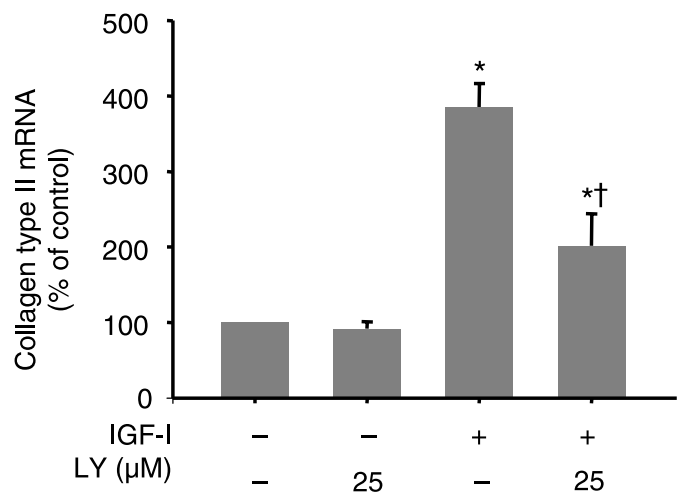

PKC

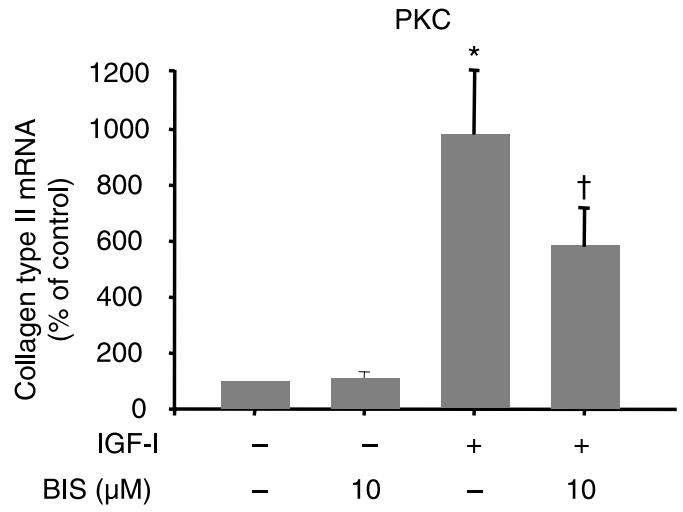

B

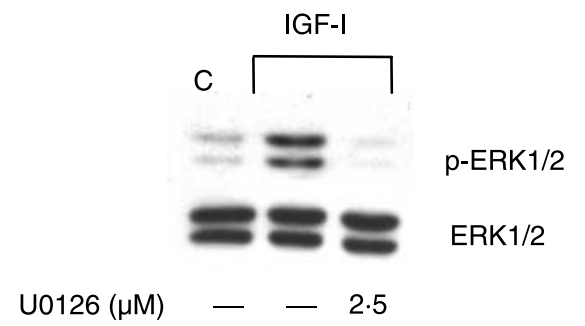

MAPK

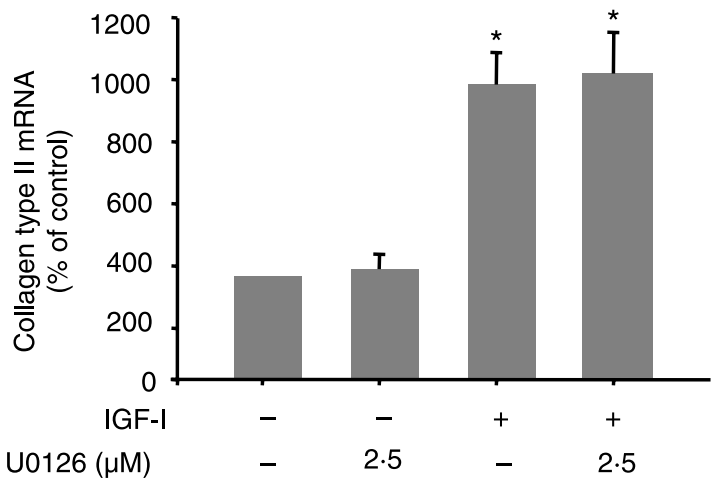

PKA

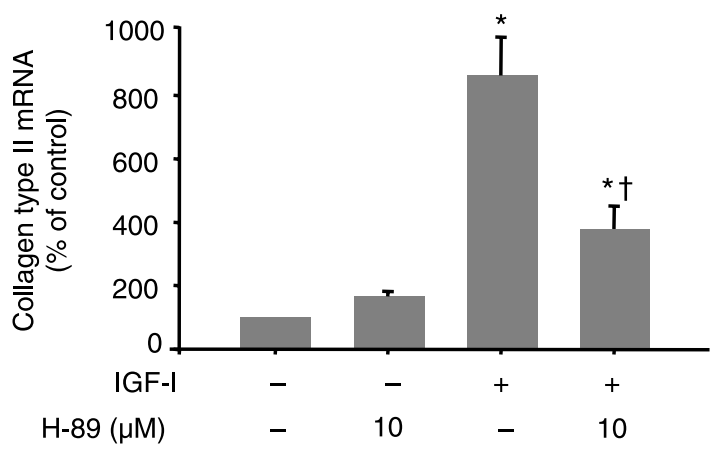

C

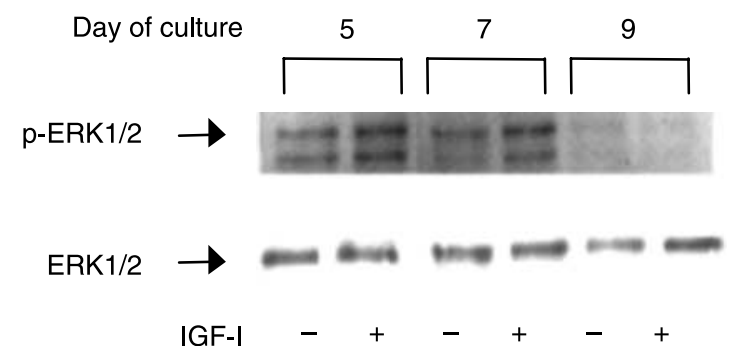

Figure 5 IGF-I-enhanced early differentiation of RCJ cells, as assessed by collagen type II gene expression, is mediated through the PI-3 kinase, PKA and PKC signaling pathways. (A) RCJ cells were cultured in differentiating medium from day 4 onwards. At day 7 of culture, cells were serum-starved for $12 \mathrm{~h}$ and stimulated by IGF-I $(100 \mathrm{ng} / \mathrm{ml})$ in the presence or absence of specific inhibitors of the different signaling pathways (LY294002 (LY) for the PI-3 kinase pathway; U0126 for the MAPK/ERK1/2 pathway; bisindolylmaleimide (BIS) for the PKC pathway; H-89 for the PKA pathway). After $12 \mathrm{~h}$, total RNA was extracted and collagen type II mRNA expression was measured by quantitative RT-PCR. Each experiment was repeated at least thrice. The columns represent the mean \pm s.E. Statistics by ANOVA. ${ }^{\star} P<0.05$ vs control; ${ }^{\dagger} P<0.05$ vs IGF-I. (B) The MAPK/ERK1/2 inhibitor U0126 $(2.5 \mu \mathrm{M})$ blocks ERK1/2 phosphorylation. After $12 \mathrm{~h}$ of starvation, cells were treated with IGF-I and the MAPK/ERK1/2 inhibitor U0126 for $1 \mathrm{~h}$. The blot represents one typical experiment of a total of two. (C) Phosphorylation of ERK1/2 both under baseline conditions and in response to IGF-I decreases during the process of differentiation of RCJ cells. RCJ cells were cultured in differentiating medium from day 4 onwards. At the indicated time points, cells were serum-starved for $12 \mathrm{~h}$ and treated with or without IGF-I for $1 \mathrm{~h}$. Cell lysates were subjected to Western immunoblotting and the membrane was probed with specific antibodies against the phosphorylated and unphosphorylated form of ERK1/2. The blot represents one typical experiment of a total of two. 
presence or absence of specific pharmacological inhibitors of defined pathways for $12 \mathrm{~h}$. As shown in Fig. 3A, the PI-3 kinase pathway inhibitor LY 294002 blocked completely the IGF-I-induced phosphorylation of AKT in a concentration of $25 \mu \mathrm{M}$ on day 7 and day 14 of culture. These results indicate that IGF-I is capable of stimulating the PI-3 kinase pathway during the entire period of differentiation. U0126 specifically inhibited the MAP kinase pathway, not the PI-3 kinase pathway, and LY294002 specifically inhibited the PI-3 kinase pathway, not the MAP kinase pathway (Fig. 3B).

It has been shown previously that translocation from the cytoplasm to the cell membrane is required for the activation of PKC isoenzymes (Newton 1995) and PKA isoenzymes (Meinkoth et al. 1993). We therefore determined whether IGF-I stimulates the respective pathways by translocation of PKC $\alpha$ and PKA $\alpha$ cells were incubated with IGF-I, PMA as an activator of the PKC pathway and the respective inhibitors, followed by preparation of cytosol, membrane, and nuclear fractions by ultracentrifugation and immunoblotting with specific antibodies. PKC $\alpha$ migrated at an approximate molecular mass of $80 \mathrm{kDa}$ and was predominantly found in untreated cells at day 7 of culture in the cytosolic fraction (Fig. 4A). Treatment with IGF-I $(100 \mathrm{ng} / \mathrm{ml})$ or PMA $(1 \mu \mathrm{M})$ for $30 \mathrm{~min}$ stimulated the translocation of PKC $\alpha$ from the cytosol predominantly to the cell membrane and to a lesser extent to the nuclear fractions (Fig. 4A, upper panel). The PKC inhibitor BIS blocked this translocation completely. In contrast, this translocation of PKC $\alpha$ from the cytosol to the cell membrane in response to IGF-I was clearly diminished on day 14 of culture (Fig. 4A, lower panel). PKA $\alpha$ migrated at an approximate molecular mass of $40 \mathrm{kDa}$ and was also predominantly found in the cytosolic fraction in control cells. Stimulation with IGF-I on day 7 of culture led to a translocation of PKA $\alpha$ from the cytosol predominantly to the cell membrane; the PKA inhibitor H-89 reduced this translocation (Fig. 4B, upper panel). In contrast, this translocation of PKA $\alpha$ from the cytosol to the cell membrane in response to IGF-I was clearly diminished on day 14 of culture (Fig. 4B, lower panel). These results indicate that IGF-I activates the PKC and PKA pathways predominantly during early chondrocyte differentiation.

As shown in Fig. 5A, IGF-I-enhanced early differentiation as assessed by collagen type II mRNA expression
Pl-3 kinase
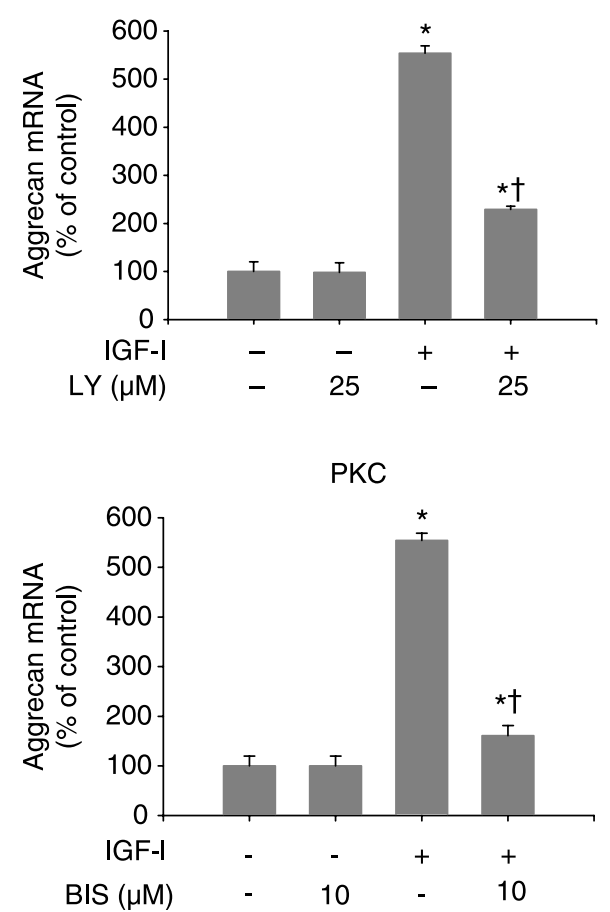

MAPK
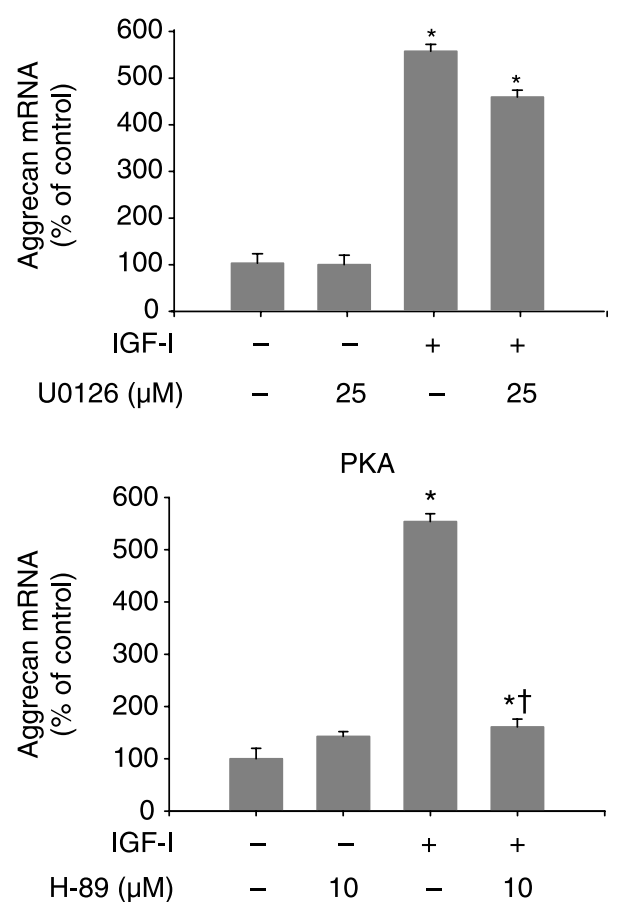

Figure 6 IGF-I-enhanced early differentiation of RCJ cells, as assessed by aggrecan gene expression, is mediated through the PI-3 kinase, PKA and PKC signaling pathways. Under the same experimental conditions as for expression analysis of collagen type II (see Fig. 5), aggrecan mRNA was measured by quantitative RT-PCR. Each experiment was repeated at least thrice. The columns represent the mean \pm s.E. Statistics by ANOVA. * $P<0.05$ vs control; ${ }^{\dagger} P<0.05$ vs IGF-I. 
was sensitive to the respective inhibitors of the PI-3 kinase, PKC and PKA pathways and not affected by MAPK/ERK1/2 inhibition. Comparable results were obtained for aggrecan gene expression as a marker for early chondrocyte differentiation (Fig. 6). The MAPK/ ERK1/2 inhibitor U0126 was used at a concentration of $2.5 \mu \mathrm{M}$, which is capable of blocking ERK1/2 phosphorylation after $12 \mathrm{~h}$ of incubation (Fig. 5B). Consistent with these results is that the activity of the MAP kinase pathway as assessed by phosphorylation of ERK1/2 declined during the process of cell differentiation, both under baseline conditions and in response to IGF-I (Fig. 5C). Taken together, these results indicate that the PI-3 kinase and the $G$ protein signaling pathways mediate the IGF-I-enhanced early differentiation of RCJ cells, while the MAPK/ERK1/2 pathway is not involved in this process.

Terminal differentiation of RCJ cells was assessed by ALP, Ihh, and collagen type X gene expression. At day 14 of culture, coincubation with the PI-3 kinase pathway inhibitor LY294002 significantly blocked the IGF-I-

Pl-3 kinase
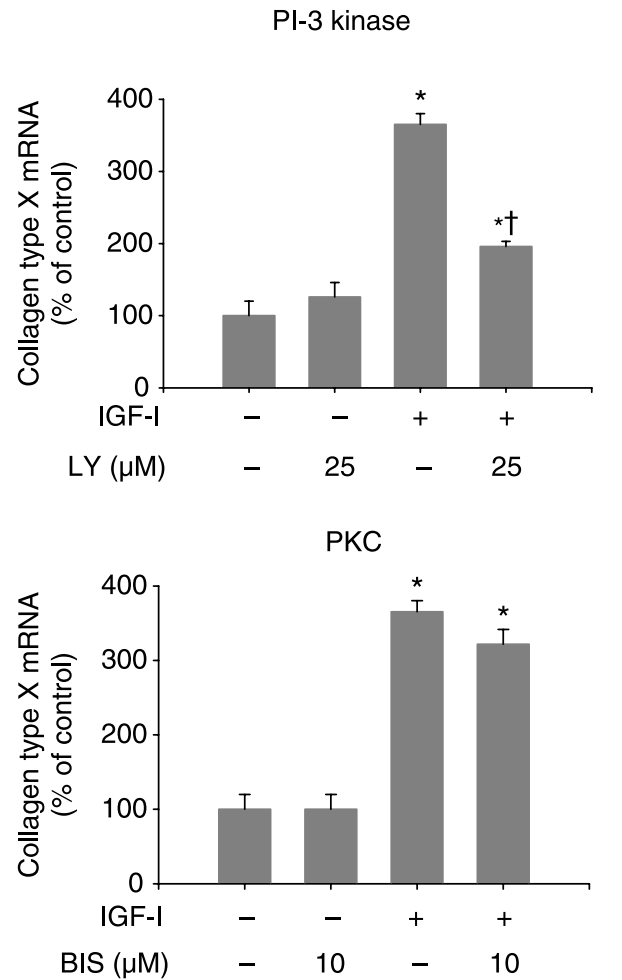

driven gene expression of ALP, Ihh, and collagen type $\mathrm{X}$, while coincubation with the respective inhibitors of the other pathways did not blunt this IGF-I-effect (Figs 7-9). This observation that PKC and PKA pathways are no more active for IGF-I-signaling during terminal differentiation is supported by our previous observations that IGF-I on day 14 of culture is no more capable of activating the PKC and PKA pathways compared with day 7 of culture (Fig. 4A and B, lower panels). Taken together, these data indicate that of the four IGF-Irelated signaling cascades investigated, only the PI-3 kinase pathway is required for early and terminal differentiation of RCJ cells in response to IGF-I.

\section{Cross-talk between the PI-3 kinase, PKC and PKA pathways in response to IGF-I in differentiating RCJ cells}

The data described above suggest that the differentiating action of IGF-I in RCJ cells is dependent upon several intracellular signaling molecules. To determine

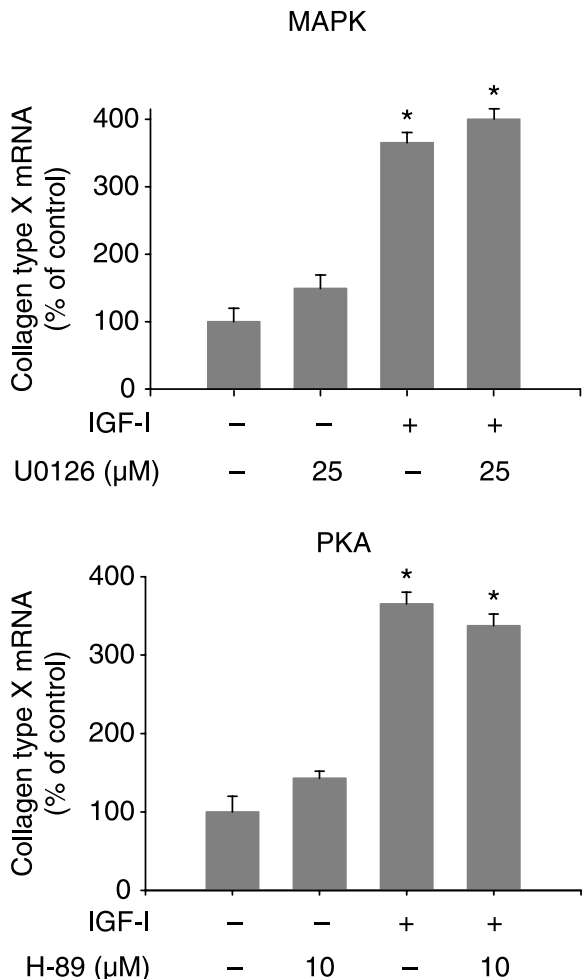

Figure 7 IGF-I-enhanced terminal differentiation of RCJ cells, as assessed by collagen type $\mathrm{X}$ gene expression, is mediated through the PI-3 kinase signaling pathway, not through the MAPK/ERK $1 / 2$, PKC or PKA pathways. RCJ cells were cultured in differentiating medium from day 4 onwards. At day 14 of culture, cells were serum-starved for $12 \mathrm{~h}$ and stimulated by IGF-I $(100 \mathrm{ng} / \mathrm{ml})$ in the presence or absence of specific inhibitors of the different signaling pathways (LY294002 (LY)) for the PI-3 kinase pathway; U0126 for the MAPK/ERK1/2 pathway; bisindolylmaleimide (BIS) for the PKC pathway; $\mathrm{H}-89$ for the PKA pathway). After $12 \mathrm{~h}$, total RNA was extracted and collagen type $\mathrm{X}$ mRNA expression was measured by quantitative RT-PCR. Each experiment was repeated at least thrice. The columns represent the mean \pm s.E. Statistics by ANOVA. ${ }^{*} P<0.05$ vs control; ${ }^{\dagger} P<0.05$ vs IGF-I. 
Pl-3 kinase
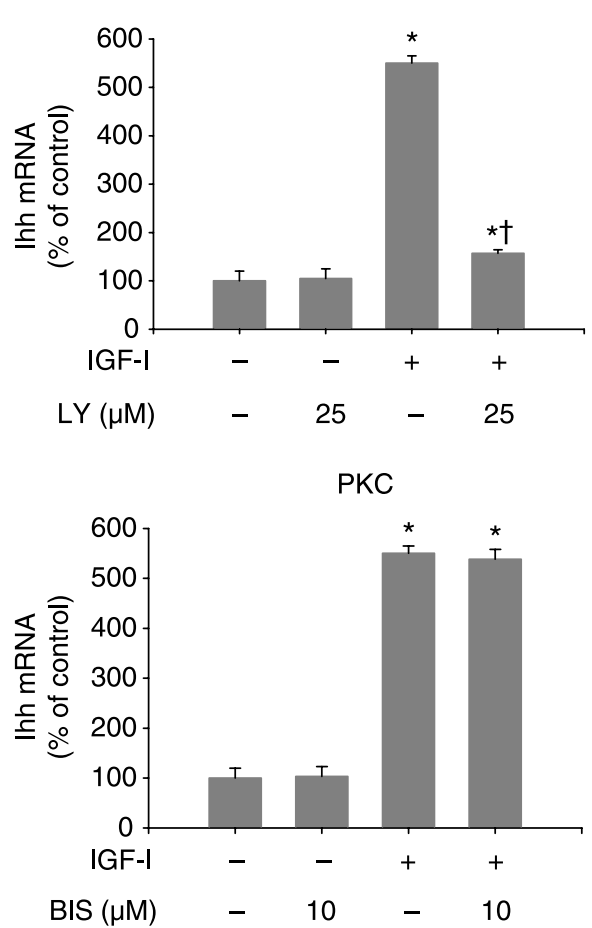

MAPK
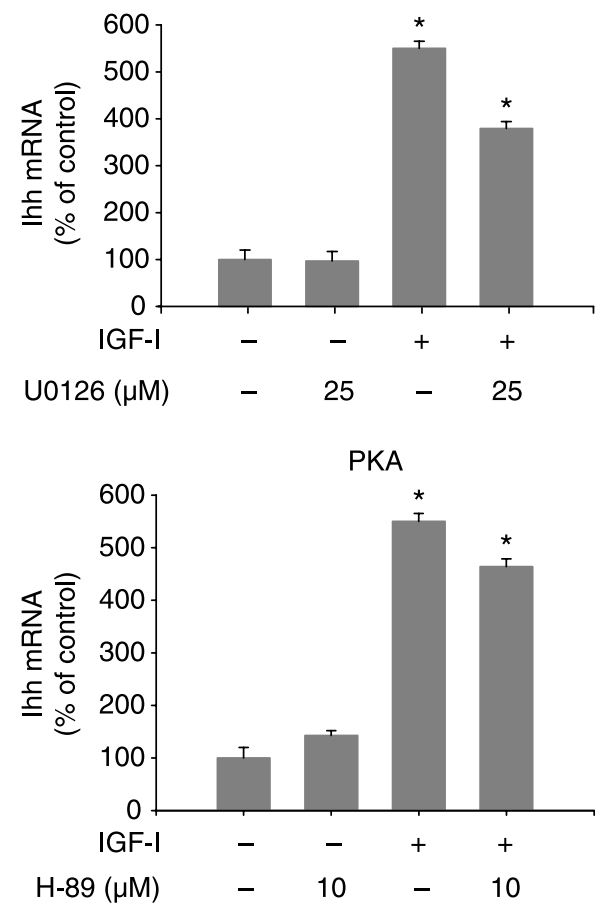

Figure 8 IGF-I-enhanced terminal differentiation of RCJ cells, as assessed by Indian hedgehog (Ihh) gene expression, is mediated through the $\mathrm{PI}-3$ kinase signaling pathway, not through the MAPK/ERK1/2, PKC or PKA pathways. Under the same experimental conditions as for expression analysis of collagen type $X$ (see Fig. 7), Ihh mRNA was measured by quantitative RT-PCR. Each experiment was repeated at least thrice. The columns represent the mean \pm s.E. Statistics by ANOVA. ${ }^{*} P<0.05$ vs control; ${ }^{\dagger} P<0.05$ vs IGF-I.

potential interrelationships among these signaling molecules, the respective effect of a combination of these inhibitors on IGF-I-enhanced RCJ cell differentiation was examined. Consistent with the data shown in Fig. 5, coincubation with the PKC inhibitor BIS reduced the IGF-I-induced collagen type II mRNA expression by $40 \%$, while coincubation with the PI-3 kinase inhibitor LY294002 suppressed IGF-I-induced collagen type II mRNA to a greater extent (80\%) (Fig. 10A). Coincubation with these two inhibitors did not have an additive inhibitory effect on IGF-I-induced collagen type II mRNA expression. In contrast, coincubation of the PKA inhibitor H-89 with LY294002 diminished IGF-Iinduced collagen type II expression to a significantly greater extent than coincubation with each inhibitor alone (Fig. 10B). These data are consistent with the hypothesis that activation of the PKC pathway in response to IGF-I occurs downstream of the PI-3 kinase pathway, while activation of the PKA pathway in response to IGF-I is independent of an intact PI-3 kinase pathway. Similarly, coincubation of the PKA inhibitor H-89 with the PKC inhibitor BIS had an additive inhibitory effect on IGF-I-induced collagen type II mRNA expression (Fig. 10C), consistent with the hypothesis that these two pathways are independently activated by IGF-I. Furthermore, IGF-I enhanced the phosphorylated PKC subunit $\theta$ (Fig. 10D). This activation was sensitive not only to the inhibition of the PKC pathway with BIS as expected, but also sensitive to the inhibition of the PI-3 kinase with LY294002 (Fig. 10D).

\section{Discussion}

Growth plate chondrocytes are important target cells both for circulating and locally synthesized IGF-I. We therefore sought to define the intracellular signal transduction pathways, which mediate the differential regulation of chondrocyte proliferation vs differentiation in response to IGF-I. We found that IGF-I-driven chondrocyte proliferation is mediated by the PI-3 kinase, the MAPK/ERK1/2 and the PKA pathways, while the PKC pathway played only a minor role. We concede that results obtained from experiments in a cell line such as RCJ cells might not be applicable to the 


\section{PI-3 kinase}
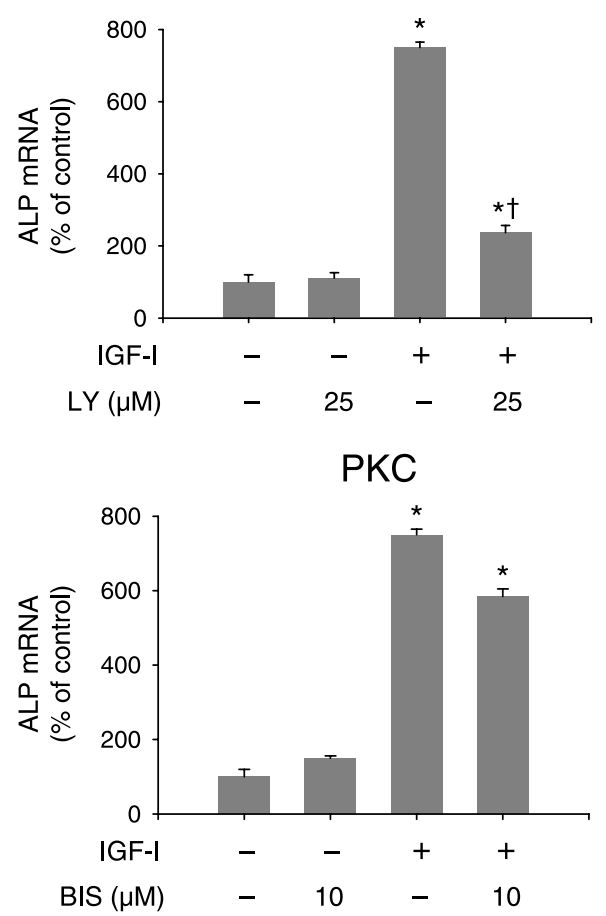

MAPK

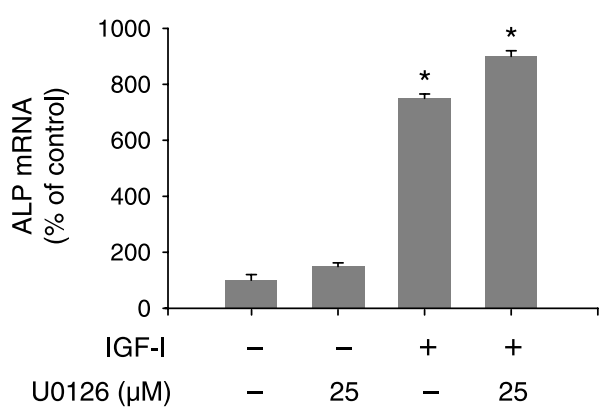

PKA

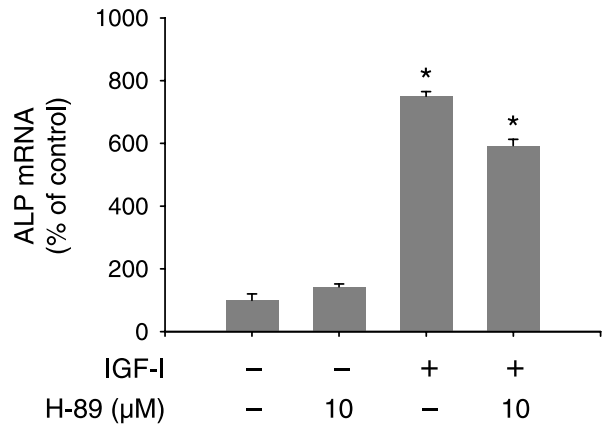

Figure 9 IGF-I-enhanced terminal differentiation of RCJ cells, as assessed by alkaline phosphatase (alp) gene expression, is mediated through the PI-3 kinase signaling pathway, not through the MAPK/ERK1/2, PKC or PKA pathways. Under the same experimental conditions as for expression analysis of collagen type $X$ (see Fig. 7), ALP mRNA was measured by quantitative RT-PCR. Each experiment was repeated at least thrice. The columns represent the mean \pm S.E. Statistics by ANOVA. ${ }^{\star} P<0.05$ vs control; ${ }^{\dagger} P<0.05$ vs IGF-I.

growth plate of the whole animal. However, we have observed previously that IGF-I-enhanced cell proliferation in rat growth plate chondrocytes in primary culture is also mediated through the PI-3 kinase and the MAPK/ERK1/2 pathways (Kiepe et al. 2005). These congruent data indicate that our observations in RCJ cells apply to growth plate chondrocytes in general.

The involvement of the PKC and PKA pathways in IGFI-driven mitogenesis of articular chondrocytes has been described previously (Taylor et al. 1988). It was recently reported that IGF-I signals mitogenesis and survival in osteoblastic cells through parallel, partly overlapping intracellular pathways involving PI-3 kinase, MAPK/ ERK1/2, and $\mathrm{G}_{\beta \gamma}$ subunits (Grey et al. 2003). These data indicate that IGF-I exerts its mitogenic effect in chondrocytes and osteoblasts by the use of comparable intracellular signaling pathways. In this context, it should be noted that the activation of different signaling pathways involved in IGF-I-mediated cell proliferation is clearly cell-type specific. For example, the proliferation of fetal brown adipocytes in response to IGF-I is mediated through activation of the MAPK/ERK1/2 pathway (Porras et al. 1998), whereas parallel PI-3 kinase and
MAPK/ERK1/2 pathways subserve the mitogenic action of IGF-I in cardiomyocytes (Sundgren et al. 2003). Interestingly, in the skeletal myoblast cell line L6A1 only the MAPK/ERK1/2 pathway, not the PI-3 kinase pathway, is responsible for the mitogenic response of IGF-I (Samuel et al. 1999).

IGF-I is not only an important endocrine and paracrine/autocrine regulator of chondrocyte proliferation, but also enhances chondrocyte differentiation in vivo, because IGF-I knockout-mice exhibit smaller hypertrophic chondrocytes than their wild-type counterparts (Wang et al. 1999, 2004). These knockout data are consistent with previous in vitro data in primary rat chondrocytes (Ohlsson et al. 1994). We demonstrate here for the first time that IGF-I also enhances differentiation of RCJ cells. In our model, differentiation was assessed by cell morphology and marker molecules of early (collagen type II and aggrecan) and terminal (collagen type $\mathrm{X}$, Ihh, and ALP) cell differentiation. Interestingly, IGF-I-enhanced early cell differentiation was mediated only through the PI-3 kinase, PKC and PKA pathways, while an intact MAPK/ ERK1/2 pathway was not required. Consistent with 
A

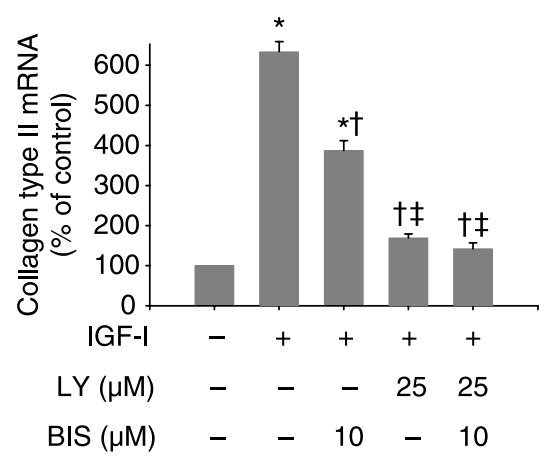

B

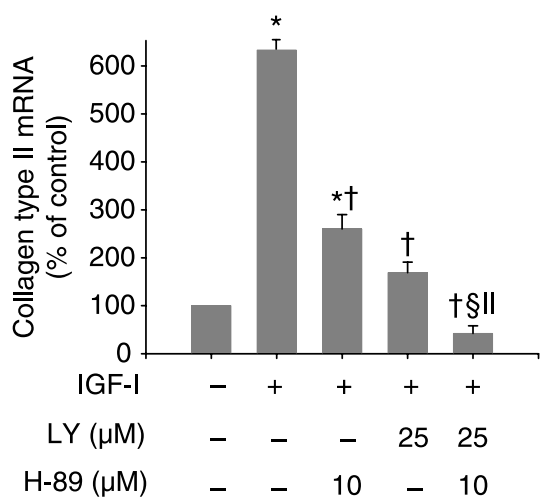

C

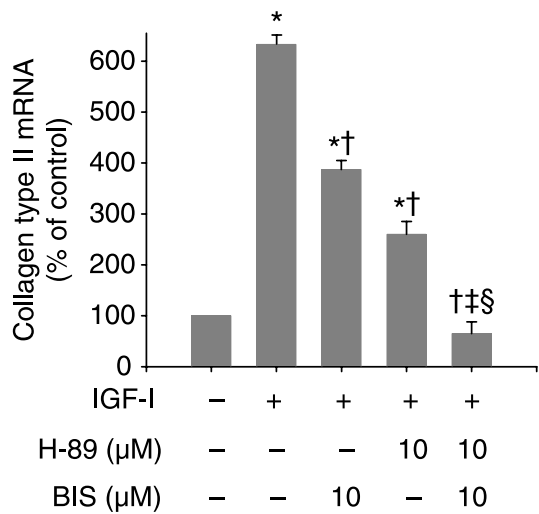

D

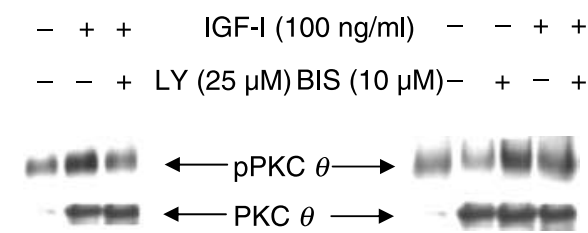

Figure 10 Cross-talk between the PI-3 kinase, PKC and PKA pathways in response to IGF-I in differentiating RCJ cells. (A-C) $\mathrm{RCJ}$ cells were cultured in differentiating medium from day 4 onwards. At day 7 of culture, cells were serum-starved for $12 \mathrm{~h}$ and stimulated with IGF-I $(100 \mathrm{ng} / \mathrm{ml})$ in the presence or absence of specific inhibitors of the respective signaling pathways (LY294002 (LY) for the PI-3 kinase pathway, bisindolylmaleimide (BIS) for the PKC pathway, $\mathrm{H}-89$ for the PKA pathway). After $12 \mathrm{~h}$, total RNA was extracted and collagen type II mRNA expression was measured by quantitative RT-PCR. Each experiment has been repeated at least thrice. The columns represent the mean \pm S.E. these data is our observation that the phosphorylation state of ERK1/2 decreased during spontaneous differentiation of RCJ cells, and IGF-I lost its capability to phosphorylate ERK1/2 after day 7 of culture (Fig. 5C). These data are in agreement with the findings of Phornphutkul et al. (2004) who observed minimal ERK response to IGF-I in hypertrophic ATDC5 cells, but the functional role of other IGF-related signaling pathways were not studied by these investigators. Taken together, these data indicate that the MAPK/ERK1/2 pathway is being inactivated both during spontaneous and IGF-Imediated early differentiation of RCJ cells. The former finding is supported by the observation that in articular chondrocytes the phosphorylation pattern of ERK was inversely proportional to spontaneous cell differentiation as assessed by type II collagen expression (Zimmermann \& Moelling 1999), indicating that also in this chondrocyte cell culture model the MAPK/ ERK1/2 pathway is being inactivated during cell differentiation. These data are consistent with observations in human articular chondrocytes in which IGF-I enhanced differentiation as assessed by proteoglycan synthesis via the PI-3 kinase pathway (Starkman et al. 2005).

The IGF-I-driven gene expression of ALP, Ihh, and collagen type $\mathrm{X}$, other marker molecules of terminal chondrocyte differentiation, were only mediated through the PI-3 kinase pathway, not the MAPK/ERK1/2 pathway (Figs 7-9). Hence it appears that chondrocytes, when they progress from the proliferative state to early and terminal differentiating cells, progressively inactivate several IGF-I-related intracellular signaling pathways beside the PI-3 kinase pathway (Figs 4 and 5C).

We observed that during differentiation of RCJ cells, there is a cross-talk between the IGF-I-induced activation of the PI-3 kinase pathway with the PKC pathway, but not between the other IGF-I-related pathways. Furthermore, inhibition of the PI-3 kinase pathway in RCJ cells reduced the expression of the pPKC $\theta$ isoform, suggesting that PKC is downstream of the PI-3 kinase pathway. This observation is consistent with data in limb bud mesenchymal cells during micromass culture in which PI-3 kinase activation is required for the

Statistics by ANOVA. ${ }^{\star} P<0.05$ vs control; ${ }^{\dagger} P<0.05$ vs IGF-I; ${ }^{\ddagger} P<$ 0.05 vs IGF-I plus BIS; ${ }^{\S} P<0.05$ vs IGF-I plus $\mathrm{H}-89$; " $P<0.05$ vs IGF-I plus LY. (D) At day 7 of culture, cells were serum-starved for $12 \mathrm{~h}$ and incubated with IGF-I ( $100 \mathrm{ng} / \mathrm{ml})$ for $1 \mathrm{~h}$ in the presence or absence of specific inhibitors of the different signaling pathways (LY for the PI-3 kinase pathway; BIS for the PKC pathway), at the indicated concentrations. Cell lysates were subjected to Western immunoblot analysis and the respective membranes were probed with specific antibodies against pPKC $\theta$ and PKC $\theta$. A representative autoradiograph of a total of three independent experiments is shown. 


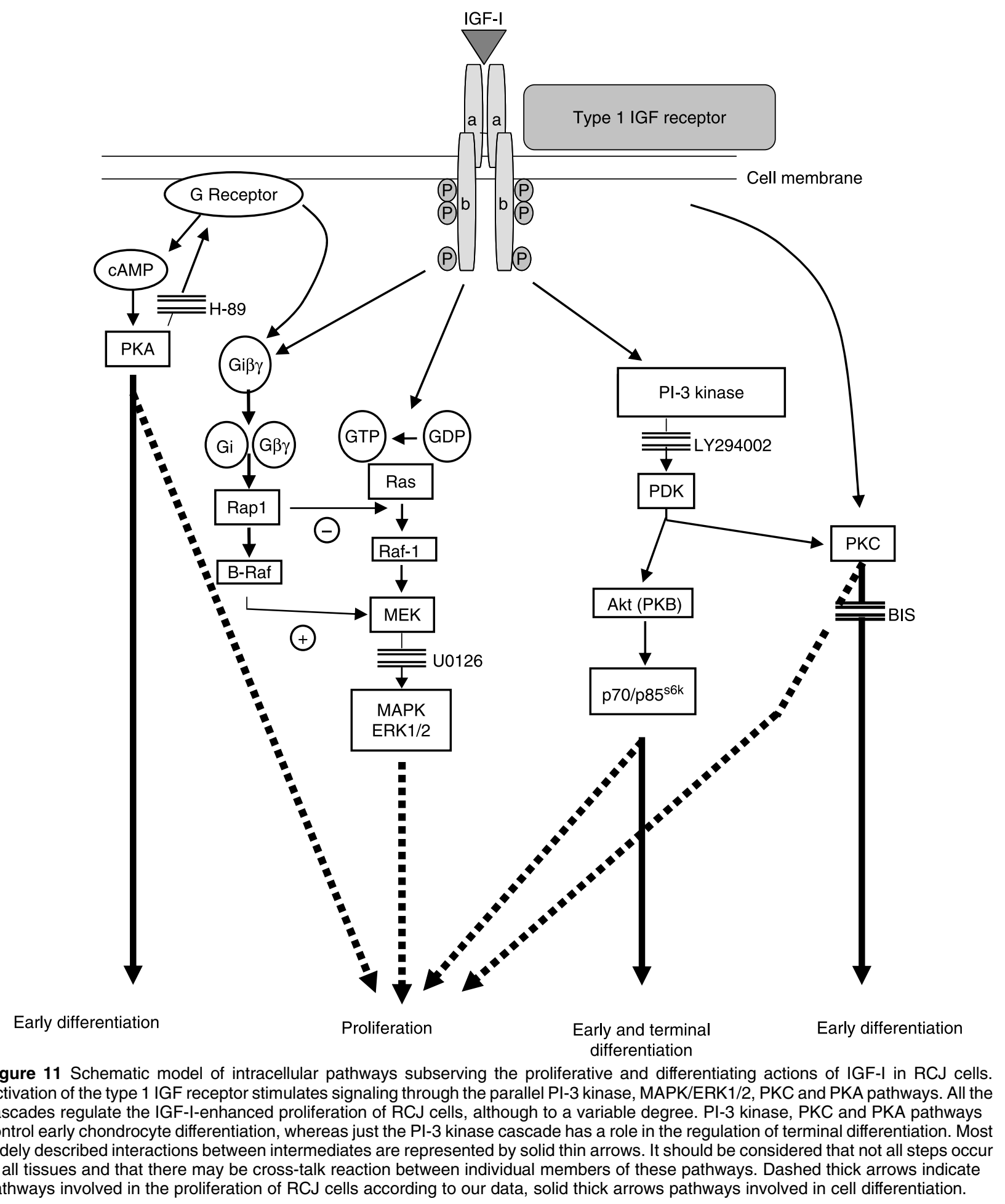

expression and activation of PKC-alpha in response to IGF-I (Oh \& Chun 2003).

Cross-talks between the PI-3 kinase and MAP$\mathrm{K} / \mathrm{ERK} 1 / 2$ signaling pathways have been reported.
For example, in differentiating articular chondrocytes, IGF-I activates PI-3 kinase signaling, which is associated with an inhibition of the phosphorylation of ERK1/2 (Oh \& Chun 2003). We observed in RCJ cells that the 
IGF-I-induced phosphorylation of ERK1/2 was not affected by inhibiting either the PI-3 kinase or the PKC pathway (data not shown). These data suggest that the MAPK/ERK1/2 pathway in RCJ cells is independent of the PI-3 kinase or PKC pathway during early differentiation of RCJ cells. Taken together, these data indicate that during differentiation of RCJ cells, there is only a cross-talk between the IGF-I-induced activation of the PI-3 kinase pathway with the PKC pathway, but not between the other IGF-I-related pathways.

In conclusion, our data indicate that IGF-I exerts its differential effect on chondrocyte proliferation vs differentiation through the use of at least four partially interacting intracellular signaling pathways, whose activity is temporarily regulated. When chondrocytes progress from proliferating cells to early and terminally differentiating cells, they progressively inactivate IGF-Irelated intracellular signaling pathways. This mechanism might be essential for the complex and cell stage-specific anabolic action of IGF-I in the growth plate.

\section{Acknowledgements}

We thank A Spagnoli for generously providing the RCJ3.1C5.18 cell line.

\section{Fundings}

This work was supported by a research grant from the Faculty of Medicine, University of Heidelberg and the Eli Lilly International Foundation. D K was a recipient of a scholarship from the Deutsche Forschungsgemeinschaft (DFG) (Graduiertenkolleg Experimentelle Nieren- und Kreislaufforschung). The authors declare that there is no conflict of interest that would prejudice the impartiality of this scientific work.

\section{References}

Adi S, Bin-Abbas B, Wu N-Y \& Rosenthal SM 2002 Early stimulation and late inhibition of extracellular signal-regulated kinase $1 / 2$ phosphorylation by IGF-I: a potential mechanism mediating the switch in IGF-I action on skeletal muscle cells differentiation. Endocrinology 143 511-516.

Cohen M, Kam Z, Addadi L \& Geiger B 2006 Dynamic study of the transition from hyaluronan- to integrin-mediated adhesion in chondrocytes. EMBO Journal 25 302-311.

Coolican SA, Samuel DS, Ewton DZ, McWade FJ \& Florini JR 1997 The mitogenic and myogenic actions on insulin-like growth factors utilize distinct signaling pathways. Journal of Biological Chemistry 272 6653-6662.

Daaka Y, Luttrell LM \& Lefkowitz RJ 1997 Switching of the coupling of the beta2-adrenergic receptor to different $\mathrm{G}$ proteins by protein kinase A. Nature 390 88-91.

Dufourny B, Alblas J, van Teeffelen HA, van Schaik FM, van der Burg B, Steenbergh PH \& Sussenbach JS 1997 Mitogenic signaling of insulin-like growth factor I in MCF-7 human breast cancer cells requires phosphatidylinositol 3-kinase and is independent of mitogen-activated protein kinase. Journal of Biological Chemistry 272 31163-31171.

Grey A, Chen Q, Xu X, Callon K \& Cornish J 2003 Parallel phosphatidylinositol-3 kinase and p42/44 mitogen-activated protein kinase signaling pathways subserve the mitogenic and antiapoptotic actions of insulin-like growth factor I in osteoblastic cells. Endocrinology 144 4886-4893.

Grigoriadis AE, Heersche JN \& Aubin JE 1996 Analysis of chondroprogenitor frequency and cartilage differentiation in novel family of clonal chondrogenic rat cell lines. Differentiation 60 299-307.

Hoeflich A, Reisinger R, Schuett BS, Elmlinger MW, Russo VC, Vargas GA, Jehle PM, Lahm H, Renner-Muller I \& Wolf E 2004 $\mathrm{Peri} /$ nuclear localization of intact insulin-like growth factor binding protein-2 and a distinct carboxyl-terminal IGFBP-2 fragment in vivo. Biochemical and Biophysical Research Communications 324 705-710.

Hömme M, Schmitt CP, Himmele R, Hoffmann GF, Mehls O \& Schaefer F 2003 Vitamin D and dexamethasone inversely regulate parathyroid hormone-induced regulator of $\mathrm{G}$ protein signaling-2 expression in osteoblast-like cells. Endocrinology 144 2496-2504.

Kaliman P, Canicio J, Shepherd PR, Beeton CA, Testar X, Palacin M \& Zorzano A 1998 Insulin-like growth factors require phosphatidylinositol 3-kinase to signal myogenesis: dominant negative p85 expression blocks differentiation of L6E9 muscle cells. Molecular Endocrinology 12 66-77.

Kiepe D, Andress DL, Mohan S, Standker L, Ulinski T, Himmele R, Mehls O \& Tönshoff B 2001 Intact IGF-binding protein-4 and -5 and their respective fragments isolated from chronic renal failure serum differentially modulate IGF-I actions in cultured growth plate chondrocytes. Journal of the American Society of Nephrology 12 2400-2410.

Kiepe D, Ciarmatori S, Hoeflich A, Wolf E \& Tönshoff B 2005 IGF-I stimulates cell proliferation and induces IGFBP-3 and IGFBP-5 gene expression in cultured growth plate chondrocytes via distinct signaling pathways. Endocrinology 146 3096-3104.

Kiepe D, Ciarmatori S, Haarmann A \& Tönshoff B 2006 Differential expression of IGF system components in proliferating vs. differentiating growth plate chondrocytes: the functional role of IGFBP5. American Journal of Physiology. Endocrinology and Metabolism 290 E363-E371.

Kronenberg HM 2003 Developmental regulation of the growth plate. Nature 423 332-336.

Lai LP \& Mitchell J 2005 Indian hedgehog: its roles and regulation in endochondral bone development. Journal of Cellular Biochemistry 96 1163-1173.

Lunstrum GP, Keene DR, Weksler NB, Cho Y-J, Cornwall M \& Horton WA 1999 Chondrocyte differentiation in a rat mesenchymal cell line. Journal of Histochemistry and Cytochemistry 47 1-6.

Lupu F, Terwilliger JD, Lee K, Segre GV \& Efstratiadis A 2001 Roles of growth hormone and insulin-like growth factor 1 in mouse postnatal growth. Developmental Biology 229 141-162.

McDougall S, Fu YH, Lowe GN, Williams A, Polendo R, Benya PD, Iida-Klein A, Fang MA \& Hahn TJ 1996 Surface adhesion-mediated regulation of chondrocyte-specific gene expression in the nontransformed RCJ3.1C5.18 rat chondrocyte cell line. Journal of Bone and Mineral Research 11 1130-1138.

McEwen DG, Green RP, Naski MC, Towler DA \& Ornitz DM 1999 Fibroblast growth factor receptor 3 gene transcription is suppressed by cyclic adenosine $3^{\prime}, 5^{\prime}$-monophosphate. Identification of a chondrocytic regulatory element. Journal of Biological Chemistry 274 30934-30942.

Meinkoth JL, Alberts AS, Went W, Fantozzi D, Taylor SS, Hagiwara M, Montminy M \& Feramisco JR 1993 Signal transduction through the cAMP-dependent protein kinase. Molecular and Cellular Biochemistry 127-128 179-186. 
Monsonego E, Halevy O, Gertler A, Hurwitz S \& Pines M 1995 Growth hormone inhibits differentiation of avian epiphyseal growth-plate chondrocytes. Molecular and Cellular Endocrinology 114 35-42.

Mrsny RJ, Birrell GB, Volwerk JJ, Widdicombe JH \& Griffith OH 1988 A novel approach to the ultrastructural localization of cell surface receptors: affinity-gold labeling of Na, K-ATPase. European Journal of Cell Biology 45 200-208.

Newton AC 1995 Protein kinase C: structure, function, and regulation. Journal of Biological Chemistry 270 28495-28498.

Ogata T, Iijima S, Hoshikawa S, Miura T, Yamamoto S, Oda H, Nakamura K \& Tanaka S 2004 Opposing extracellular signalregulated kinase and Akt pathways control Schwann cell myelination. Journal of Neuroscience 24 6724-6732.

Oh CD \& Chun JS 2003 Signaling mechanisms leading to the regulation of differentiation and apoptosis of articular chondrocytes by insulinlike growth factor-1. Journal of Biological Chemistry 278 36563-36571.

Ohlsson C, Isaksson O \& Lindahl A 1994 Clonal analysis of rat tibia growth plate chondrocytes in suspension culture - differential effects of growth hormone and insulin-like growth factor I. Growth Regulation 4 1-7.

Olney RC, Wang J, Sylvester JE \& Mougey EB 2004 Growth factor regulation of human growth plate chondrocyte proliferation in vitro. Biochemical and Biophysical Research Communications 317 1171-1182.

Parrizas M, Saltiel AR \& Leroith D 1997 Insulin-like growth factor 1 inhibits apoptosis using the phosphatidylinositol 3'-kinase and mitogen-activated protein kinase pathways. Journal of Biological Chemistry 272 154-161.

Petley T, Graff K, Jiang W, Yang H \& Florini J 1998 Variation among cell types in the signaling pathways by which IGF-I stimulates specific cellular responses. Hormone and Metabolic Research 31 70-76.

Phornphutkul C, Wu KY, Yang X, Chen Q \& Gruppuso PA 2004 Insulin-like growth factor-I signaling is modified during chondrocyte differentiation. Journal of Endocrinology 183 477-486.

Porras A, Alvarez AM, Valladares A \& Benito M 1998 p42/p44 mitogenactivated protein kinases activation is required for the insulin-like growth factor-I/insulin induced proliferation, but inhibits differentiation, in rat fetal brown adipocytes. Molecular Endocrinology 12 825-834.

Reinecke M, Schmid AC, Heyberger-Meyer B, Hunziker EB \& Zapf J 2000 Effect of growth hormone and insulin-like growth factor (IGFI) on the expression of IGF-I messenger ribonucleic acid and peptide in rat tibial growth plate and articular chondrocytes in vivo. Endocrinology 141 2847-2853.

Roesler WJ, Vandenbark GR \& Hanson RW 1988 Cyclic AMP and the induction of eukaryotic gene transcription. Journal of Biological Chemistry 263 9063-9066.

Samuel DS, Ewton DZ, Coolican SA, Petley TD, McWade FJ \& Florini JR 1999 Raf-1 activation stimulates proliferation and inhibits IGFstimulated differentiation in L6A1 myoblasts. Hormone and Metabolic Research 31 55-64.

Sirover MA 1997 Role of the glycolytic protein, glyceraldehyde-3phosphate dehydrogenase, in normal cell function and in cell pathology. Journal of Cellular Biochemistry 66 133-140.

Sive JI, Baird P, Jeziorsk M, Watkins A, Hoyland JA \& Freemont AJ 2002 Expression of chondrocyte markers by cells of normal and degenerate intervertebral discs. Molecular Pathology 55 91-97.
Spagnoli A, Hwa V, Horton WA, Lunstrum GP, Roberts CT Jr, Chiarelli F, Torello M \& Rosenfeld RG 2001 Antiproliferative effects of insulin-like growth factor-binding protein-3 in mesenchymal chondrogenic cell line RCJ3.1C5.18. Journal of Biological Chemistry 276 5533-5540.

Starkman BG, Cravero JD, Delcarlo M \& Loeser RF 2005 IGF-I stimulation of proteoglycan synthesis by chondrocytes requires activation of the PI 3-kinase pathway but not ERK MAPK. Biochemical Journal 389 723-729.

Stork PJS \& Schmitt JM 2002 Crosstalk between cAMP and MAP kinase signaling in the regulation of cell proliferation. Trends in Cell Biology 12 258-266.

Sundgren NC, Giraud GD, Schultz JM, Lasarev MR, Stork PJ \& Thornburg KL 2003 Extracellular signal-regulated kinase and phosphoinositol-3 kinase mediate IGF-1 induced proliferation of fetal sheep cardiomyocytes. American Journal of Physiology. Regulatory, Integrative and Comparative Physiology 285 R1481-R1489.

Taylor AM, Dandona P, Morrell DJ \& Preece MA 1988 Insulin like growth factor-I, protein kinase-C, calcium and cyclic AMP: partners in the regulation of chondrocyte mitogenesis and metabolism. FEBS Letters 236 33-38.

Tsakiridis T, Tsiani E, Lekas P, Bergman A, Cherepanov V, Whiteside C \& Downey GP 2001 Insulin, insulin-like growth factor-I and plateletderived growth factor activate extracellular signal-regulated kinase by distinct pathways in muscle cells. Biochemical and Biophysical Research Communications 288 205-211.

Valverde AM, Lorenzo M, Navarro P \& Benito M 1997 Phosphatidylinositol 3-kinase is a requirement for insulin-like growth factor I-induced differentiation, but not for mitogenesis, in fetal brown adipocytes. Molecular Endocrinology 11 595-607.

van der Eerden BC, Karperien M \& Wit JM 2003 Systemic and local regulation of the growth plate. Endocrine Reviews 24 782-801.

Wang J, Zhou J \& Bondy CA 1999 IGF1 promotes longitudinal bone growth by insulin-like actions augmenting chondrocyte hypertrophy. FASEB Journal 13 1985-1990.

Wang J, Zhou J, Cheng CM, Kopchick JJ \& Bondy CA 2004 Evidence supporting dual, IGF-I-independent and IGF-I-dependent, roles for $\mathrm{GH}$ in promoting longitudinal bone growth. Journal of Endocrinology 180 247-255.

Weksler NB, Lunstrum GP, Reid ES \& Horton WA 1999 Differential effects of fibroblast growth factor (FGF) 9 and FGF2 on proliferation, differentiation and terminal differentiation of chondrocytic cells in vitro. Biochemical Journal 342 677-682.

Yoon YM, Kim SJ, Oh CD, Ju JW, Song WK, Yoo YJ, Huh TL \& Chun JS 2002 Maintenance of differentiated phenotype of articular chondrocytes by protein kinase $\mathrm{C}$ and extracellular signal-regulated protein kinase. Journal of Biological Chemistry 277 8412-8420.

Zimmermann S \& Moelling K 1999 Phosphorylation and regulation of Raf by Akt (protein kinase B). Science 286 1741-1744.

Received in final form 19 December 2006

Accepted 3 January 2007

Made available online as an Accepted Preprint 12 January 2007 